\title{
Correction to: Stability of ALE Ricci-Flat Manifolds Under Ricci Flow
}

\author{
Alix Deruelle ${ }^{1} \cdot$ Klaus Kröncke $^{2}$ (i) \\ Published online: 12 August 2021 \\ (c) The Author(s) 2021
}

\section{Correction to: The Journal of Geometric Analysis (2021) 31:2829-2870 https://doi.org/10.1007/s12220-020-00376-4}

The article 'Stability of ALE Ricci-Flat Manifolds Under Ricci Flow', written by Alix Deruelle and Klaus Kröncke was originally published Online First without open access. After publication in Volume 31, Issue 3, page 2829-2870 the author decided to opt for open choice and to make the article an open access publication. Therefore, the copyright of the article has been changed to (C) The Author(s) 2021 and the article is forthwith distributed under a Creative Commons Attribution 4.0 International License, which permits use, sharing, adaptation, distribution and reproduction in any medium or format, as long as you give appropriate credit to the original author(s) and the source, provide a link to the Creative Commons licence, and indicate if changes were made. The images or other third party material in this article are included in the article's Creative Commons licence, unless indicated otherwise in a credit line to the material. If material is not included in the article's Creative Commons licence and your intended use is not permitted by statutory regulation or exceeds the permitted use, you will need to obtain permission directly from the copyright holder. To view a copy of this licence, visit http://creativecommons.org/licenses/by/4.0.

The original article has been corrected.

The original article can be found online at https://doi.org/10.1007/s12220-020-00376-4.

Klaus Kröncke

klaus.kroencke@uni-hamburg.de

Alix Deruelle

alix.deruelle@imj-prg.fr

1 Institut de mathématiques de Jussieu, 4, Place Jussieu, Boite Courrier 247, 75252 Paris, France

2 Fachbereich Mathematik, Universität Hamburg, Bundesstraße 55, 20146 Hamburg, Germany 
Open Access This article is licensed under a Creative Commons Attribution 4.0 International License, which permits use, sharing, adaptation, distribution and reproduction in any medium or format, as long as you give appropriate credit to the original author(s) and the source, provide a link to the Creative Commons licence, and indicate if changes were made. The images or other third party material in this article are included in the article's Creative Commons licence, unless indicated otherwise in a credit line to the material. If material is not included in the article's Creative Commons licence and your intended use is not permitted by statutory regulation or exceeds the permitted use, you will need to obtain permission directly from the copyright holder. To view a copy of this licence, visit http://creativecommons.org/ licenses/by/4.0/.

Publisher's Note Springer Nature remains neutral with regard to jurisdictional claims in published maps and institutional affiliations. 